Resumen por el autor, Ralph Dougall Lillie.

La histogénesis temprana de la sangre en Bufo balophilus Baird y Girard.

El autor ha estudiado el desarrollo temprano de las células sanguíneas en los estados arvarios hasta los $19 \mathrm{~mm}$ de longitud. Las cólulas sanguíneas primarias se originan principa mente en la masa celular mesodérmica ventral. Eistas células dan lugar a critroblastos primitivos y a grandes linfocitos. Los primeros adquicren la forma definitiva acumulando hemoglobina y multiplicándose por mitosis, transformándose en eritrocitos primitivos. En los estados estudiados no ha encontrado el autor eritropoiesis definitiva. En la masa celular ventral se originan grandes linfocitos, a expensas del endotelio endocárdico y del endotelio general, o a expensas de células mesenquimatosas no diferenciadas. De los grandes linfocitos se derivan pequeños linfocitos y los tres tipos de células granulosas, cosinófilas, basófilas y células especiales o neutrófilas.

Translation by José H'. Nonidez

Carnegie Institution of Washington 
AUTHOR'S ABSTRACT OF IHIS PAPER ISSCED

BY THE AIBLIOGRAPHIC SERVICE, BEPTEMEER 29

\title{
THE EARLY HISTOGENESIS OF THE BLOOD IN BUFO HALOPHILUS BAIRD AND GIRARD
}

\author{
RALPH DOUGALL LILLIE
}

Division of Anatomy of Stanford University Medical School

SEVEN FIGURES

CONTENTS

Introduction and literature................................. 209

Material and methods........................................ 211

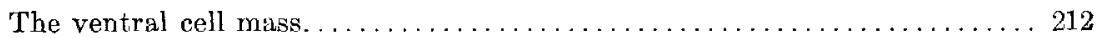

The primitive blood-cells................................... 214

The stage of differentiation of the primitive blood-cells into primitive erythroblasts and large lymphocytes. The loss of the yolk........ 218

The further differentiation of the primitive erythrocyte stem.......... 221

The hematopoietic tissue of the mesonephros.................... 222

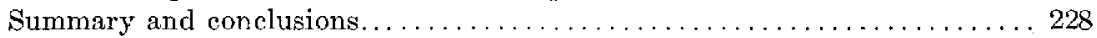

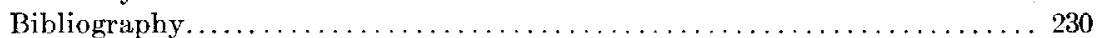

\section{INTRODUCTION AND LITERATURE}

The histogenesis of the blood of Amphibia has occupied the attention of but few writers. Among these the earlier ones and Maximow ('10) in Rana hold that the primitive blood-cells give rise only to red corpuscles, while in other vertebrates, such as Lepidosiren (Bryce, '04), birds and Tropidonotus (Danchakoff, '08 a, 16 a), Chelonia (Jordan and Flippin, '13), mammals (Maximow, '09 a, and Jordan, '10), and in certain Amphibia themselves, (Bufo, Mietens, '10), the same cells give rise to two lines of descent, viz., an erythrocyte and a leucocyte stem. Further, it has been shown that this erythrocyte stem is a transitory one, giving place later to a definitive one which is a branch of the leucocyte line.

This difference between the Amphibia and other vertebrates and especially between the two Amphibian forms, suggested the 
subject of the present paper: a reëxamination of the early development of the blood elements in Bufo, and for this purpose the California species B. halophilus Baird and Girard was found to be the most convenient.

Bryce ('04) derives the blood and endothelium from the splanchnic mesenchyme. The yolk-laden primitive blood-cells quickly differentiate into a larger type with peripheral fibrils: the erythroblasts, and a smaller lymphoid form. The larger type pass over into yolk-free, oval, flattened cells in which hemoglobin appears. The loss of the yolk may precede the appearance of hemoglobin by a short time. In the next phase erythropoiesis continues, the stem cell now being a large mononuclear cell. The mesenchyme gives rise to large mononuclear cells, polymorphonuclear leucocytes, and granulocytes. The splanchnic mesenchyme, the intrahepatic mesenchyme, and the interstitial mesenchyme of the pro- and mesonephros are the chief sites of blood formation. The last, at least, sets free leucocytes into the blood, as they are more numerous in the cardinal vein than in the aorta. Likewise, small lymphocytes appear. With the development of the spleen further hematopoiesis is confined to it, to the lymphorenal tissue, and to the gut-wall mesenchyme. The splenic trabeculum cells give rise to erythrocytes through large lymphocytes, also to lympholeucocytes, finely and coarsely granular eosinophils, and basophil granulocytes. In the later stages the lymphorenal tissue is almost entirely lympholeucopoietic. Leucoand granulopoiesis are strictly extravascular, erythopoiesis intravascular. This last conclusion is reached also by Bizzozero ('90) in birds, Danchakoff ('08 a, '16 a) in birds and reptiles, Jordan and Flippin ('13) in reptiles, and Maximow ('09 a, '10) in mammals, selachians, and amphibians. And when erythrocytes are formed outside of the vessels they soon degenerate, while granulocytes are only formed intravascularly where the circulation has been stopped up (Danchakoff, '08 b).

In the main the differentiation of the blood-cells in the other vertebrates follows the outline given by Bryce for Lepidosiren (Maximow, '09 a, '10; Danchakoff, '08 a, '16 a; Mietens, '10; Jordan and Flippin, '13). 
In birds (Danchakoff, '08 a) and reptiles (Jordan and Flippin, '13; Danchakoff, ' 16 a) the primitive blood-cell is morphologically a large lymphocyte and the primitive erythropoiesis gives way gradually to the definitive. While in Selachia (Maximow, '10 a), Dipnoi (Bryce, '04), Amphibia (Mietens, '10), and Mammalia (Maximow, '09 a) the primitive blood-cell is a distinct form and the formation of primitive erthrocytes is separated by an interval from that of the definitive cells.

Schridde ('07, '08), in human embryos of 1 to $13 \mathrm{~mm}$., finds that the first blood-cells all differentiated into nucleated erythrocytes, whose nuclei began to fragment in the $6-\mathrm{mm}$. stage. Later, when blood formation in the liver commences, parenchyme cells give rise to myeoblasts, giant-cells, and erythroblasts, lymphocytes not appearing until much later.

Van der Stricht ('91, '92, '95, '99), in mammals and birds, and Weber ('07 a, b), in birds, find that all the first blood-cells become' erythrocytes and that no white cells occur in the blood stream at first.

Stockard ('15 a, b) asserts that in Fundulus embryos without circulation erythrocytes, endothelium cells, and leucocytes all have distinct origins, no white cells being formed intravascularly and all the first blood-cells arising from a definite anlage and passing over into erythrocytes, and are not interrelated, no bloodcells being formed from endothelium. He observed red corpuscles outside of the anlage, but accounted for them by assuming a temporary circulation. White cells, on the other hand, arise from the general mesenchyme. Reagan ('15 b, '17) and Reagan and Thorington ('15) found that all the body mesenchyme of Fundulus could furnish both blood- and endothelium cells.

\section{MATERIAL AND METHODS}

My material consisted of eggs and larvae of Bufo halophilus $B$. and $G$., from the closing of the neural groove to the beginning of the metamorphosis. In this study only the earlier stages, up to $19-\mathrm{mm}$. body length, are treated fully. The larvae were fixed. in Zenker-formalin for four to six hours, ten parts of formalin to. 
one hundred of sublimate-Müller being the proportion used. The larvae were extracted three to six days in iodized alcohol and preserved in 85 per cent alcohol. Imbedding was in paraffin, in gelatin-paraffin (Weber, '14), and in celloidin-paraffin.

Serial sections $5 \mu$ in thickness of the larvae up to $9-\mathrm{mm}$. body length were made. From the later stages the mesonephros, liver, pancreas, and heart were dissected out and sectioned alone.

For stains Hansen's iron hematoxylin with eosin or orange $G$, Dominici's eosin-orange G-toluidin blue, Maximow's eosin-azure II, and thionin were used, the sections being cleared in xylene and mounted in xylene-damar. Wright's stain diluted with two parts of water was also used, staining being sufficient in about ten minutes, the differentiation being secured in alcohol rather than in water. As controls and for comparison smear preparations of adult blood and bone marrow were used.

\section{THE VENTRAL CELL MASS}

No discussion of the origin of this cell mass, whether entodermal or mesodermal, will be made here, the evidence for its mesodermal origin being deemed sufficient. In a larva of 2.5to $3-\mathrm{mm}$. body length it forms two plates on the ventrolateral aspects of the yolk mass. It is distinguished from the latter by the greater number of nuclei, the somewhat smaller size of the yolk granules, and a line of demarkation, which, although not too well defined, is nevertheless distinguishable. There is no striking differenee in nuclear structure.

This mass is apparently syncytial in character, at least, no cell boundaries are evident by ordinary methods. I believe that is largely due to the pale character of the cytoplasm, which is greatly obscured by the large rounded or elliptical yolk granules. The same indefiniteness of cell outline obtains in the yolk mass itself. But occasionally polygonal cells are seen outlined by pigment, and more clearly by the blue stained (eosin-azure II) gelatin of the imbedding mass. These cells are rich in yolk, less so than the yolk entoderm cells, their yolk granules being about $6 \mu$ long and half as broad. These granules stain readily with 
eosin or orange $G$ and very intensely and tenaciously with iron hematoxylin. When blood elements of later stages are stained with Heidenhain's iron hematoxylin and eosin the granules of the eosinophil leucocytes readily give up the black color and become bright red. Bryce ('04) states that these granules were, in the younger stages, either derived from, or actually were finely divided yolk matter.

At the 3-mm. stage some few of the cells are seen to be rounding up and detaching themselves from the mass.

When stained with Dominici's eosin-orange G-toluidin blue, the nuclei of these cells take on a deeper blue than those of the mesenchyme, showing a finely reticular structure with dark blue nodal points. Most of the cells contain one or two purple stained, large, smoothly rounded nucleoli. With Wright-alcohol the nuclei show the reticular structure even better, the reticulum seeming more irregular. Chromatin particles lie at the nodes. The karyoplasm is basophil, with a tinge of pink in some cells, thus suggesting the faintly oxyphil condition of the later stages. The cytoplasm is usually colorless or nearly so, becoming increasingly basophil soon after, and contains many small brownish black pigment granules, which are present throughout all the cells of the embryo.

The mesenchyme cell of this stage $(3 \mathrm{~mm}$.) is taking on a spindle form. It has a basophil cytoplasm with fewer and smaller yolk granules than the cells of the blood anlage. The nucleus is clearer and poorer in chromatin, which lies in discrete, deeply staining particles at the nodes of a loose network of lightly colored linin threads. A deeply stained nucleolus is present.

The cell of the blood anlage and the mesenchyme cell differ in the reaction of the cytoplasm, in the number and size of the yolk granules, and in the character of the nucleus. They are alike in the possession of small dark brown pigment granules and in that both are frequently seen in mitosis. 


\section{THE PRIMITIVE BLOOD-CELLS}

The ventral cell mass breaks up into large round cells at about 3 - to $3.5-\mathrm{mm}$. body length. The peripheral layer of the splanchnic mesoderm forms an endothelial wall for the ventral sinus. The wall next the yolk mass is incomplete, there being but few endothelium cells on that side, so that the cavity is in part closed in above by the yolk mass itself. This sinus seems to correspond to an omphalomesenteric vein, for in later stages it can be traced forward on each side into the sinus venosus.

Endothelium cells are seen in various parts of the body. These are elongated cells with clear elliptical nuclei containing one or two large nucleoli and but little chromatin. The karyoplasm is clear and colorless. The conspicuous nucleolus is round or oval and stains violet blue with eosin-azure II. The eytoplasm is basophil.

In thcse earlier stages the endothelia of the blood-vessels do not seem complete, but present gaps here and there. Mietens ('10) finds this condition also in B. vulgaris.

In larvae of $3-$ to $3.5-\mathrm{mm}$. body length the ventral cell mass becomes resolved into its constituent elements. The cells gradually break apart, the mass as a whole enlarges, free space appears within the endothelial wall, and the cells round up into spherical elements which float free in the plasma. Not until about the $4 \mathrm{~mm}$. stage are these free rounded cells found in the cavity of the heart or in the systemic vessels. So it would appear that the breaking up of the blood anlage occurs before the commencement of the circulation rather than after.

The primitive blood-cells (fig. $1, p b c$ ) are large, spherical cells about 13.5 to $22 \mu$ in diameter, averaging 17 to $18 \mu$, heavily laden with yolk granules, which are evidently solid in nature, as they are not distorted by mutual pressure, while the nucleus is frequently compresscd and angular from the resistance of the yolk granules. There are many extra nuclear pigment granules in these and in the endothelium cells. The dark nucleus contains a considerable amount of chromatin in angular or rounded masses of varying size on a linin network. The karyoplasm is stained blue with a reddish tinge (eosin-azure II). As a rule, it is darker and 
the chromatin is more abundant than in the endothelium cells, but transition forms are found which approach the nuclear constitution of the latter. The amount of chromatin does not show any definite relation to the degree of basophilia of the cytoplasm. The chromatin, when stained with thionin, appears as angular or rounded blocks of an intensely dark blue color. The large round nucleolus or nucleoli, they being frequently two in number, stains bluish violet with eosin-azure II, and reddish violet, i.e., metaehromatically, with thionin. With the former stain it shows little color difference from chromatin itself, and, as will be seen, this difference becomes less and less apparent as development proceeds. The cytoplasm is colorless or slightly basophil. The basophilia appears especially around the periphery of the cell. In some cells no basophilia is evident, though observation is difficult on account of the large volume of yolk, but in those cells in which the yolk is decreasing in amount considerable areas of cytoplasm may be observed. When in mitosis these primitive blood-cells show larger expanses of yolk-free eytoplasm, and but little basophilia is then evident.

In these stages, 3.5- to $4.5-\mathrm{mm}$. body length, the mesenchyme cells (fig. 2, $m s$ ) become almost free from yolk. Occasional rounded cells (fig. 2, $p b c$ ), rich in yolk and morphologically identical with the primitive blood-cells, are seen in the loose mesenchyme. Two possibilities exist regarding them: that they have lagged behind the spindle cells in yolk elimination, their nuclei being modified so as to resemble those of the primitive blood-cells, or that they are primitive blood-cells which have escaped from the vessels and wandered out into the mesenchyme. The second is not excluded, but the first seems more probable, for such cells are found in the head mesenchyme before the breaking up of the ventral cell mass, while the mesenchyme cells are still yolk-laden, but are taking on spindle forms with diminishing chromatin content of their nuclei.

The steady decrease in food yolk is more evident toward the 5 -mm. stage, the larger cells becoming elongated and oval, with a more circular cross-section, and with this diminution a centriole sometimes becoming visible in the increasingly basophil cy toplasm. 
In such larvae large cells with pale cytoplasm, a large vesicular nucleus with little chromatin, a large nucleolus, and clear karyoplasm, and but little yolk are found laden with large numbers of dark brown pigment granules. These cells circulate in the blood stream, are seen passing through vascular walls, and are found in the mesenchyme outside.

In the mesenchyme are also noted a few cells which are somewhat less elongated than the rest, more rounded up, and have a more strongly basophil cytoplasm. These probably represent the first lymphoid wander-cells. 'Toward the end of the phase under description, 3 to $5 \mathrm{~mm}$., the period in which the primitive blood-cclls are the only intravascular eirculating elements aside from the pigment cells just mentioned, the mesenchyme becomes almost free from yolk, only an isolated cell here and there retaining a granule or two. At the end of this phase the primitive blood-cells have lost their spherical form and a portion of their yolk and are now roughly oval elements, all containing yolk, with cytoplasm in varying grades of basophilia, and nuclei containing somewhat variable amounts of chromatin, and slightly basophil or very slightly oxyphil karyoplasm.

My results as to the primitive blood-cells coincide fairly closely with those of Mietens ('10). He states that primitive blood-cells resemble young erythrocytes more than they do primitive leucocytes. The primitive blood-cells of Bufo vulgaris are sharply bounded, spherical cells with dark nuclei, rich in yolk. In Lepidosiren paradoxa (Bryce, '04) the primitive blood-cells are heavily laden with yolk, show a centrosome with aster, the nucleus is round or oval, not distorted by the pressure of the yolk granules as in Bufo halophilus, sometimes notched, the chromatin is in rounded karyosomes connected by delicate processes to form a reticulum. This, as may readily bo seen, corresponds closely to the structure of my primitive blood-cells. Maximow (10) characterizes the primitive blood-cells of Rana temporaria as large spherical cells, rich in yolk, and those of Acanthias vulgaris are hemoglobin-free, amoeboid, and basophil. In mammals (Maximow, '09 a) they are regularly spherical, smoothly contoured cells about 10 to $11.5 \mu$ in diameter, in the guinea- 
pig often amoeboid. The nucleus is large, surrounded by a narrow cytoplasm. It is round or slightly indented. Within it are pale karyosomes and one or more large distinct nucleoli, which stain with a reddish tinge with eosin-azure II or Dominici's stain, lying on a linin net. The cytoplasm is very finely reticular and fairly strongly basophil, more so than the cytoplasm of endothelium and mesenchyme cells. It contains clear round vacuoles, lying singly or in small groups. The nucleus is usually somewhat eccentric, with its indented side toward the broader part of the cytoplasm. On this side close against the nuclear membrane lies a very distinct, usually hemispherical attraction sphere, staining red with eosin-azure If or Dominici's stain. Around this lie many vacuoles. In iron-hematoxylin preparations a typical pair of centrosomes takes the place of the sphere. Many mitotic figures are found in these cells. Thus it may be seen that the nuclei are readily comparable in mammals and in Amphibia. The difference in the degree of basophilia in these forms may probably be attributed entirely to the presence and gradual digestion of yolk in the cytoplasm, for when the primitive blood-cells in Bufo halophilus have lost their yolk and have differentiated into red and white cells, both types show a more or less basophil cytoplasm (fig. 3). In birds and reptiles (Danchakoff, '08 a, '16 a; Jordan and Flippin, '13) the primitive bloodcells are morphologically large lymphocytes, amocboid, spherical, with a more or less broad basophil cytoplasm. They have a large clear nucleus, which may be indented, with one or two well-marked, somewhat metachromatic nucleoli and well-marked chromatin particles. The nucleus is excentric and a centriole may be present. So, in the Sauropsida the primitive blood-cells are large lymphocy tes, while in Dipnoi, Amphibia, and Mammalia they are a morphologically distinct form. They are neither red cells, nor are they white cells of any adult type. Their nuclei are in $\mathrm{B}$. halophilus distinct in character from those of the primitive erythrocytes. 
THE STAGE OF DIFFERENTIATION OF THE PRIMITIVE BLOODCELLS INTO PRIMITIVE ERYTHROBLASTS AND LARGE LYMPHOCYTES. THE.LOSS OF THE YOLK

In larvae of 5- to 6-mm. body length the primitive blood-cells lose their yolk almost completely, and differentiate into two new types, one of which is a large, oval, flattened cell with much vacuolated oxyphil cytoplasm, the primitive erythroblast, the other is morphologically identical with the large lymphocyte (fig. 3, $p . e b, l . l b, l . l c)$.

The yolk granules seem to disappear by intracellular solution, not by granular fragmentation. Vacuoles appear around their margins, enlarge and coalesce, while the yolk granule decreases in size, finally passing into the interior of the vacuole. The yolk granules become paler as they diminish and finally disappear completely. The contents of the vacuoles are clear and colorless, not staining with eosin-azure II. Bryce ('04) suggests that the yolk granules, when they disappear, may break up into granules which are eosinophil in nature, and that the early leucocytes may be concerned in the distribution of yolk material. The latter statement may be true, but as to the former, all yolk has long since disappeared from the blood-cells before the first eosinophil granulocyte appears in Bufo. We must note, however, that Bryce lacked stages which showed the complete details of the loss of the yolk, which might modify his interpretation. A third alternative exists: that the yolk granules may be extruded from the cells into the circulating blood, since one frequently sees apparently free granules in the blood stream. Usually, however, a small amount of basophil cytoplasm or a few pigment granules may be seen close to them, so it may be that they lie within a pseudopod of a cell in the next section. It seems perfectly possible, however, that the granules may be extruded from the cells and digested by the proteolytic enzymes of the blood.

Mietens (10) merely states that the yolk disappears. Bryce ('04) notes that a vacuolization of the eytoplasm occurs and seems to be associated with the disappearance of the yolk not only in the blood-cells, but in the general tissuc cells of the body as well. I have noted such an appearance in the mesenchyme cells of Bufo. 
Now as to the erythrocytoid differentiation of the primitive blood-cells. The nucleus retains its round or oval shape and its definite nuclear membrane, which may be indented by a single remaining yolk granule. The chromatin becomes much more abundant, condensing to form a heavy network. At this stage the nucleolus reacts to basic stains in practically the same manner as the chromatin of the nucleus, and as the denser network of the latter develops, the nucleolus gradually loses its identity and becomes merged in the common chromatin content of the nucleus. The exact time of its disappearance is somewhat variable, in some cases the nucleolus persisting almost up to the first appearance of hemoglobin. The karyoplasm retains its faintly oxyphil character as long as it is at all distinguishable in the increasing density of the nucleus. This forms one of the distinct differences between the early ery throblasts and the large lymphocytes. As the yolk disappears from the cytoplasm, the latter takes on an increasingly basophil reaction, varying somewhat in intensity in different cells. With the appearance of hemoglobin this blue color soon shows a gray tint tending either toward greenish or purplish, depending on whether the developing hemoglobin takes a yellow or a pink stain with eosin-azure II. The cytoplasm becomes much vacuolated, these vacuoles persisting some little time after the disappearance of the yolk. The colls are oval, but not yet flattened, with sharply defined, smooth contours which are not necessarily perfectly uniform, but do not present any evidence of amoeboid activity.

The second type of cell differentiating from the primitive blood-cell is the large lymphocyte (fig. $3, l . l b, l . l c$ ). In this process the cytoplasm of the former becomes very strongly basophil with the decrease of its food yolk. The cell outline shows strongly marked evidence of amoeboid activity. The cytoplasm of the large lymphocyte is broad, bas no definite cell membrane, and appears reticular in some cells, in others hyaline. The nucleus is round, oval, or slightly indented, the indentation frequently facing the remaining yolk, and central or excentric in position. The karyoplasm becomes typically clear and colorless. The chromatin decreases in amount and is disposed in irregularly 
scattered particles and in occasional isolated strands. A large smoothly rounded, metachromatically basophil nucleolus persists, showing but little change from the preceding stage. The cell is now a typical large lymphocyte.

Such cells arise also from other sources than the primitive blood-cells of the blood stream. Endocardial cells bulge out into the heart cavity and become constricted from the endocardium, at the same time becoming strongly basophil (fig. 3, en.c). These cells contain but little yolk, otherwise being identical with those arising from the primitive blood-cells. Endothelium cells in various parts of the body become thickened and more basophil, bulging out into the loose mesenchyme. Often free lymphoid wander-cells are seen lying in contact with these endothelia. Lymphoid wander-cells oceur in many places in the mesenchyme: in the head mesenchyme, in the interstitial spaces of the mesoncphros, around the gut. Here they arise from the indifierent mesenchyme cells by a withdrawal of their processes and an increase in the basophilia of their cytoplasm, the nuclei changing but little. It is likely that the cells resembling primitive bloodcells which were seen in the loose mesenchyme of the earlier stages ( 4 to $5 \mathrm{~mm}$.) have gone over into lymphoid wander-cells or extravascular large lymphocytes.

Although white cells do arise from these other sources, both within and outside the vessels, they are not, as Maximow ('10) claims they are in Rana temporaria, the sole source of white blood-cells, for continuous series of transitions from yolk-laden primitive blood-cells to yolk-free, and also yolk-laden, large lymphocytes are found and these yolk-laden large lymphocytes cannot have been derived from either the endocardium cells, which are poor in yolk, or from the now almost yolk-free endothelium and mesenchyme cells.

At this stage, 5 - to 6 -mm. body length, the liver anlage is invaded by blood-vessels. These narrow ressels contain but few blood-cells, so the hematopoietic function of this organ is not yet developed at this period. 


\section{THE FURTHER DIFFERENTIATION OF THE PRTMITIVE ERYTHROCYTE STEM}

At the end of the last stage, $6 \mathrm{~mm}$., the primitive erythroblast is a large, ellipsoidal, vacuolated cell with a large, round or oval, chromatin-rich nucleus. This cell is not at all flattened, but is somewhat irregular in contour. With eosin-azure II its cytoplasm stains a light blue with no trace of pink.

Between 6- and 6.5-mm. body length hemoglobin first appears, the cytoplasm now taking on a pink stain with triacid. With eosin-azure II some edls may now show a greenish-gray color, some a pink tint, but many are still pure blue. They are beginning to flatten, but a considerable margin of cytoplasm still shows on all sides of the nucleus. This body uniformly appears darker than the cytoplasm and contains much more chromatin than that of the lymphoid type. The erythroblasts now far outnumber the lymphocytes in the heart blood and frequently present mitotic figures.

Between 6.5 - and $7-\mathrm{mm}$. body length the erythroblasts rapidly approach the definitive form (fig. $4, p . e b$ ) of the adult erythrocyte, there being now very little cytoplasm between the nucleus and the flattened sides of the cell. With eosin-azure II the cytoplasm is of a gray color with elements of both blue and pink visible. The pink is more pronounced in some cells than in others, and is determined by the increased development of hemoglobin in their cytoplasm. Many vacuoles still remain, disappearing last from near the nucleus. A cell containing a single yolk granule may still be met with oecasionally.

From the $7-\mathrm{mm}$. stage on the majority of the cells, and soon all of them, are oxyphil, hemoglobin-carrying primitive erythrocytes. Through all the stages studied, up to $38-\mathrm{mm}$. body length, no definitive erythropoicsis was obscrved. Mietens (10) states that in Bufo vulgaris definitive erythropoiesis does not set in until the time of the metamorphosis.

At the 8-mm. stage the primitive erythrocytes (fig. 5, p.ec) are pink stained, hemoglobin-containing, oval, flattened, biconvex, sharp-bordered dises with a spherical, flattened, or oval chromatin-rich nucleus, showing an indistinct chromatin network. 
Most of these cells have lost the vacuoles of the differentiation stages. The dark brown pigment granules of the primitive bloodcells are still present, but are very few in number. These cells are still found in karyokinesis in the circulation up to $37-\mathrm{mm}$. body length (and even in the young adult, also, according to Freidsohn, '10), which is as late as I have followed the larval development.

\section{THE HEMATOPOLETIC TISSUE OF THE MESONEPHROS}

In a stage where the mesonephros is as yet represented only by a single Wolffian duct, larvae of 8 - to $9-\mathrm{mm}$. body length, one sees mesenchyme cells multiplying in the neighborhood of this duct, between it and the aorta, and undergoing a lymphoid metamorphosis (fig. 6). All transitions from branched and spindle-shaped lightly basophil mesenchyme cells $(\mathrm{ms})$ to strongly basophil, rounded, amoeboid lymphoid wander-cells (l.w.c) may be found in a single field of the microscope. In addition, lymphoid cells with basophil cytoplasm and nuclei in varying degrees of polymorphism are seen in 9-mm. larvae. All transitions from slightly indented to horseshoe-shaped nuclei are found. The more polymorphous of these nuclei show an increase in chromatin and its progressive condensation about the periphery.

In this stage the first granulocytes appear. An eosinophil cell with about twenty bluish-red (eosin-azure II) granules is shown at e.c in figure 6 . The first special cells are seen in this stage or slightly later (fig. 7, s.c.), and have also been noted in the circulating blood, but in very small numbers.

In a short time, however, the mesonephroic tubules become convoluted and the interstitial tissue increases greatly in amount. Much more granulopoietic differentiation is now seen. At first only eosinophil and special cells appear, but at about $16-\mathrm{mm}$. body length mast cells and small lymphocytes are likewise found. Since at this stage all the later forms of the blood elements, except spindle-cells, are represented, a description of each and its development may be taken up at this point. 
Small lymphocytes. A few typical small lymphocytes (fig. 7, s.lc) are seen in the 16-mm. stage and more in later stages. These cells have proportionately large nuclei and a narrow rim of basophil cytoplasm. The chromatin is disposed in large angular blocks, some typical 'Radkern' or wheel-like nuclei being found, but no nucleoli may be distinguished.

Transition stages from large to small lymphocytes are found. It is evident that the small lymphocyte is a more highly differentiated cell form than the large lymphocyte, for when the latter differentiates to a granulocyte similar changes in the nuclear constitution occur, the chromatin becoming more abundant and the nucleolus disappearing.

Eosinophil cells. These cells, in the mature state in which they are found intravascularly, possess horseshoe-shaped, lobed, or segmented nuclei, cytoplasm which takes very little stain with eosin-azure II, and many coarse round eosinophil granules of varying size. The nuclear chromatin is larger in amount than in the large lymphocyte, but is still quite variable, being disposed primarily in contact with the well-defined nuclear membrane and then in variable density over the nuclear network. In this network no nucleolus can be distinguished. The karyoplasm is clear and almost colorless to eosin-azure II. The larger oxyphil granules often show a clear area in the center, staining more deeply peripherally, while in other cells smaller, more decply staining, homogeneous granules occur. Thesc granules become very numerous in mature cells, which may occasionally show mitotic figures. Such cells may readily be found in all phases of diapedesis from the tissue into the vessels. They are also found in the circulating blood. In one isolated but unmistakable case (fig. 7, e.end) an eosinophil cell was found as a part of the endothelial wall itself.

All transitions from typical large lymphocytes to mature eosinophil leucocytes are found. First a few coarse basophil granules, which, however, show no trace of metachromasia, appear, usually in the concavity of the slightly indented nucleus, soon increasing in number and changing their stain from blue to purple red with eosin-azure II; then the nuclear membrane 
becomes evident, the chromatin at the same time increasing in amount and in coarseness of karyosomes and the nucleolus losing its metachromasia and blending with the nuclear chromatin, and the cytoplasm becomes less and less strongly basophil as the nucleus assumes its final polymorphous form and the granules increase in number and come to be purely oxyphil.

Since phagocytosis of erythrocytes is absent in this extravascular tissue, it seems very improbable that these eosinophil granules arise as fragmentation derivatives of ingested hemoglobin containing cells, as maintained by Weidenreich (11).

The interpretation of the essinophil endothelium cell described above is a matter of difficulty, but it seems possible that this may be just another manifestation of the close relationship of the endothelium cell and the blood-cell. Danchakoff ( $16 \mathrm{~d}$ ) has used differentiation into similar end types as a proof of identity of stem colls in regard to the small cortical cells of the chick thymus and their mother cells. So it seems here that the differentiation of an endothelium cell into an cosinophil granulocyte would tend to show the identity of the endothelium cell with the large lymphocyte, which is the mother cell of the eosinophil granulocyte. According to the view of exogenous origin of easinophil granules, it would merely be a proof of phagocytic activity on the part of the endothelium cell. Ordinarily phagocytosis is followed by intracellular digestion, and not by the preservation of the fragments of the ingested cell as an integral part of the phagocyte, even when autogenous crythrocytes are ingested by the cndothelial phagocytes of the liver and spleen (Kyes, '15). The hemosiderin granules which are formed as a result of the intracellular digestion of red cells have no resemblance to true eosinophil granules.

Mast cells. This type of cell is first seen extravascularly in the 16-mm. stage. Maximow ('10) finds them in Rana only aifter the metamorphosis. Mietens ('10) does not find any mast cells at all, which is probably due to mast granules being soluble in such acid fixatives as he used. In Bufo halophilus these granules resist the action of water after fixation with Zenker formol. 
The mast cells are mostly extravascular; one or two only being found within the vessels in my preparations, and are vcry few in number, not more than one occurring in each section.

The nuclei are simple, round, oval, or bean-shaped. In the younger stages the nucleus is that of a large lymphocyte, round and clear, with but little chromatin in small karysomes, and a metachromatically basophil nucleolus, the cytoplasm is broad and usually slightly basophil, the granules are large, round, and comparatively few in number, staining an intensely dark purplish blue with eosin-azure II and violet red to blue violet with thionin. No variation in the staining quality of these mast granules could be found in any stage of their development. Thus the possibility of confusing the younger eosinophil granules with mast granules is excluded. In the older cells (fig. 7, m.c) the cytoplasm becomes less basophil, the mast granules increase in number, the nucleus becomes richer in chromatin, the nucleolus changes its staining quality and becomes indistinguishable from the chromatin. In some cells the chromatin is disposed in a 1ypical 'Radkern,' being distributed in large angular blocks lying against the nuclear membrane and pointing toward a centrally located one. The karyoplasm is clear and may be slightly oxy- or basophil. Transition stages between these two types, here designated as older and younger, are seen. One coll, manifestly an old one, was found, in which the chromatin was decreased in amount, the nucleus appearing vesicular, the cytoplasm was colorless and showed ragged edges, indicating fragmentation of its pcriphery. In this cell the granules were large, only about six or seven remaining. Some evidence of amoeboid activity may be noted in the contour of many of the mast cells.

Special cells. Under this head are designated many cells with purplish-pink cytoplasm and simple to polymorphous nuclei (fig. $7,8, c$ ). The more polymorphous of these nuclei may be lobed and segmented, as many as five lobes being found. Their chromatin is more or less abundant and lies along the nuclear membrane and in a chromatin net, or in small karyosomes in faintly oxyphil or colorless karyoplasm. The cytoplasm is the homogeneous, indistinctly granular, or, in a few cases, definitely 
so. Such granules are very fine, rounded, discrete, and stain purplish pink. In these cases the cytoplasm is colorless. The staining reactions of these granules will be further treated later.

Transitions from large lymphocytes to special cells are readily found. First the nucleus becomes slightly indented, then sausage shaped, the nucleolus loses its difierential stain and form and blends with the chromatin, then a pink spot appears in the blue cytoplasm (eosin-azure II) opposite the concavity of the nucleus. Or the change of stain may be more diffuse and almost simultaneous throughout the whole cytoplasm. The chromatin becomes more abundant and arranged along the nuclear membrane, which is now more evident.

One of these cells was seen in karyorrhexis. Its eosinophil cytoplasm was non-granular and contained a horseshoe-shaped nucleus whose chromatin was collected into numerous round, strongly basophil granules within the nuclear membrane, except at the tip of one lobe, where they were escaping into the cytoplasm. The karyoplasm itself was clear and colorless. Mitotic figures are not rare in the special cells.

Since it is usually stated in the literature that the special leucocytes of the Amphibia are non-granular or have at most only an azurophil granulation, I thought it worth while to investigate further the character of the fine granulation described above. It may be noted here that in air-dried films of adult blood and bone marrow of Bufo halophilus all the special leucocytes show a fine purplish-pink granulation on a clear karyoplasm when stained with Wright's stain in the customary manner.

In order to eliminate as far as possible variations due to age or differences in technique, sections of the mesonephros of a single larva of $19-\mathrm{mm}$. body length were used for the following series of staining reactions. All the stains used were differentiated in 96 per cent alcohol, except the thionin which was differentiated in absolute alcohol and cleared in xylene. The dilute Wright's and Jenner's stains mentioned were diluted to the same color tint as eosin-azure II-1:10:1 (Maximow, '09 c). 


\begin{tabular}{|c|c|c|}
\hline STAIN & TIME & RESULTS \\
\hline Jenner (strong). & $10 \mathrm{~m}$. & $\begin{array}{l}\text { Some cells show distinct pink gran- } \\
\text { ules. }\end{array}$ \\
\hline Jenner (dilute). & $24 \mathrm{hr}$. & $\begin{array}{l}\text { Some cells show very distinct pur- } \\
\text { plish-pink granules. Best granule } \\
\text { stain of all. }\end{array}$ \\
\hline Thionin (alcoholic) & $30 \mathrm{~m}$ & No granules in blue cytoplasm. \\
\hline Toluidin Blue. . & $10 \mathrm{~m}$ & No granules in blue eytoplasm. \\
\hline Eosin-azure II $(1: 10: 1)$ & $24 \mathrm{hr}$. & $\begin{array}{l}\text { Some cells show purplish-pink gran- } \\
\text { ules. }\end{array}$ \\
\hline Azure II (1:1000). & $10 \mathrm{~m}$. & $\begin{array}{l}\text { Many cells show gray or blue-gray } \\
\text { granules in blue cytoplasm. }\end{array}$ \\
\hline Wright (strong). & $10 \mathrm{~m}$ & $\begin{array}{l}\text { Some cells show purplish-pink gran- } \\
\text { ules. }\end{array}$ \\
\hline Wright (dilute) & $24 \mathrm{hr}$. & $\begin{array}{l}\text { Some cells show purplish-pink gran- } \\
\text { ules. }\end{array}$ \\
\hline $\begin{array}{c}\text { Unna's polychrome methylene } \\
\text { blue..................... }\end{array}$ & $10 \mathrm{~m}$. & No granules in blue cytoplasm. \\
\hline Ehrlich's triacid.............. & $5 \mathrm{~m}$ & $\begin{array}{l}\text { Some cells show fine red granules. } \\
\text { Most have red cytoplasm instead. }\end{array}$ \\
\hline 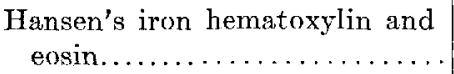 & q.s. & No granules show. \\
\hline
\end{tabular}

The conclusions led to by the above table are as follows: 1 ) these granules are not soluble in water after fixation, because when stained for twenty-four hours they are no less distinct than when they are only exposed to water for ten minutes; 2 ) they are not azurophil, because they stain with Jenner's stain and with triacid, neither of which contains any methylene azure, and because they do not stain pink with azure II or Unna's polychrome methylene blue, both of which contain methylene azure, uncombined with eosin, however; 3 ) they are neutrophil, because they do not stain with eosin, or with basic analines alone, but do stain with neutral stains; 4) they have, however, a special affinity for acid fuschin, for they stain red with triacid rather than purplish pink.

My special cells are without doubt identical with Mietens' ('10) oxyphil wander-cells. Mietens' failure to observe granules in these cells can be attributed to inappropriate fixation. Maximow ('10) speaks of special granulocytes and of special leucocytes 
with oxyphil eytoplasm without making it clear whether all the cells were granular or not. Downey (13) describes in Amblystoma special leucocytes containing many fine purplish-pink granules (Wright's stain) which he concludes are azurophil, differing, however, from the azurophil granules of the lymphocytes, and being homologous with the granules of the special leucocytes of mammals. Werzberg (11) finds in eight species of Urodela and eight species of Anura that the special leucocytes are nongranular, save in Salamandra maculosa and Rana esculenta in which he describes fine azurophil granules. In these same two species Niegelewski ('94) describes fine granules which are neutrophil to triacid. Grünberg (01) gets the same results as Werzberg. Freidsohn ('10) and Weidenreich ('11, p. 75) state that granules are lacking in the special leucocytes of Amphibia. In Rana aurora and in Batrachoseps attenuatus I was unable to find any granules in the special lcucocytes.

In larvae of 37 - to $40-\mathrm{mm}$. total length, that is, larvae which show the beginning of hind-limb buds and measure 15 to $16 \mathrm{~mm}$. from the snout to the anus, all of the above-described cell forms may be found in the loose connective tissue surrounding the bile duct. In the mesonephros there may be seen small areas in which all the cells are lymphocytes, while surrounding these islets all types of white cells are mixed. As yet, few leucocytes occur in the vessels, nor is there any definitive erythropoiesis. As in Bufo vulgaris (Mietens, '10), there is no interstitial hematopoiesis in the liver of $B$. halophilus up to this stage.

In closing, I take pleasure in thanking Prof. F. M. MacFarland for his aid and suggestions and for the use of his private room in the Hopkins Marine Station during the summer of 1916.

\section{SUMMARY AND CONCLUSIONS}

1. The primitive blood-cells arise from the ventral cell mass. Some isolated cells are found in various parts of the mesenchyme.

2 . These cells lose their yolk by intracellular solution, differentiating at the same time into primitive erythroblasts and large lymphocytes. 
3. The primitive erythroblasts soon assume the definitive form and acquire hemoglobin.

4. After this no heteroplastic formation of erythrocytes occurs, up to the latest stages studied. Homoplastic erythropoiesis continues.

5. Large lymphocytes may arise from endocardial and general endothelial cells.

6. Mesenchyme cells all over the body may develop into large lymphocytes or lymphoid wander-cells.

7. The large lymphocyte is the mother cell of all the other white blood-cells.

8. Three types of granular leucocytes occur: eosinophils, special cells, and mast cells.

9. The granules of the cosinophil cells are endogenous.

10. The special lcucocytes of Bufo halophilus contain many fine granules, which are not azurophil, but neutrophil.

The histogenetic rolations here described may be expressed by the following diagram, which is self-explanatory in the light of the foregoing account.

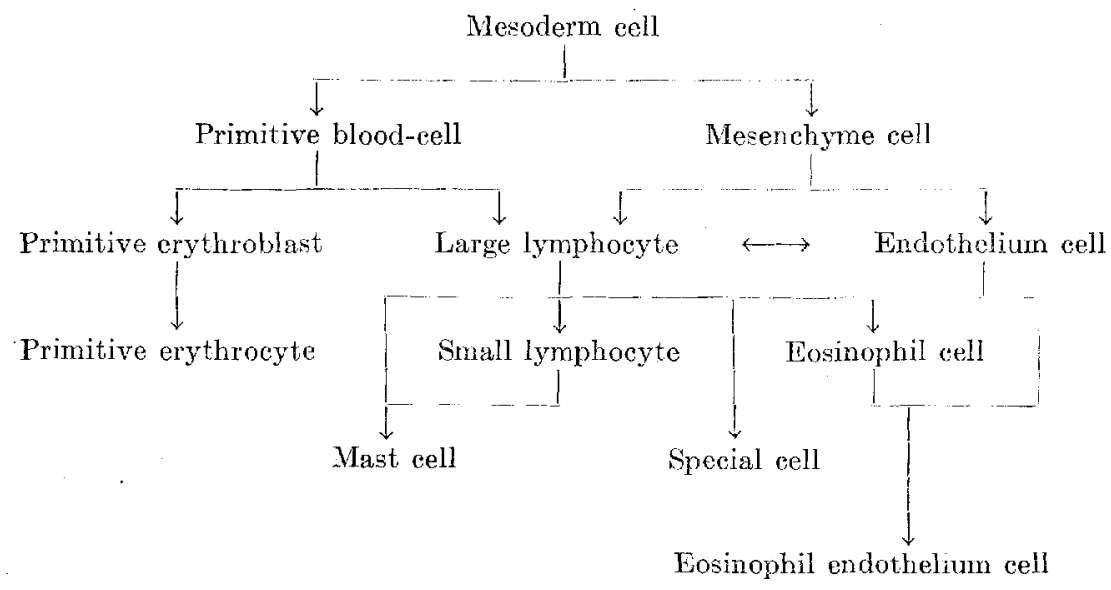




\section{BIBLIOGRAPHY}

Badertschur, J. A. 1913 Muscle degeneration and its relation to the origin of eosinophil leucocytes in Amphibia. Am. Jour. Anat., vol. 15, p. 69.

Bizzozero, G. 1890 Neue Untersuchungen über den Bau des Knochenmarkes bei den Vögeln. Arch. f. mikr. Anat., Bd. 35, S. 424.

Brycr, T. H. 1904 Histology of the blood of Lepidosiren paradoxa. T. Structure of resting and dividing corpuscles. II. Hematogenesis. $\mathrm{Tr}$. Roy. Soc. Edinburgh, vol. 41, pp. 291, 435.

Danchakoff, Vira 1908 a Untersuchungen über die Entwicklung des Blutes und Bindegewebes bei den Vögeln. I. Die erste Entstehung der Blutzellen beim Hühnerembryo und der Dottersack als blutbildendes Organ. Anat. Hefte, Bd. 37, S. 471.

$1908 \mathrm{~b}$ Untersuchungen über die Entwicklung von Blut und Bindegewebe bei Vögeln. III. Das lockere Bindegewebe des Hühnchens im fetalen Leben. Arch. f. mikr. Anat., Bd. 73, S. 117.

1916 a Über die Entwicklung des Blutes in den Blutbildungsorganen (Area vasculosa, Dottersackanhänge, Knochenmark, Thymus, Milz, und lockeres Bindegewebe) bei Tropidonotus natrix. Arch. f. mikr. Anat., Bd. 87, S. 497.

$1916 \mathrm{~b}$ Origin of the blood cells. Development of the hematopoietic organs and regeneration of the blood cells from the standpoint of the monophyletic school, Anat: Rec., vol. 10, p. 397.

$1916 \mathrm{c}$ Concerning the conception of the potentialities in the embryonic cells. Anat. Rec, vol. 10, p. 415.

$1916 \mathrm{~d}$ 'The differentiation of cells as a criterion for cell identification, considered in relation to the small cortical cells of the thymus. Jour. Exp. Med., vol. 24, p. 87.

1916 e Equivalence of different haematopoietic anlages (by the method of stimulation of their stem cells). I. Spleen. Am. Jour. Anat., vol. 20 , p. 255.

Downey, HaL 1909 The lymphatic tissue of the kidney of Polyodon spathula. Folia Haemat., Bd. 8, S. 415.

1913 The granules of the polymorphonuclear leucocytes of Amblystoma, with a few notes on the spindle cells and erythrocytes of this animal. Anat. Anz., Bd. 44, S. 309.

1914 Heteroplastic development of eosinophil leucocytes and of haematogenous mast cells in bone marrow of guinea-pig. Anat. Rec., vol. 8 .

1915 The origin and development of eosinophil leucocytes and of haematogenous mast cells in the bone marrow of adult guinea-pig. Folia Haemat., Bd. 19, S. 148.

Emmes, V. 1915 Concerning certain cellular elements in the coleomic cavities and mesenchyma of the mammalian embryo. Am. Jour. Anat., vol. 220, p. 73.

Freidsohn, A. 1910 Zur Morphologie des Amphibienblutes. Zugleich ein Beitrag zur Lehre von der Differenzierung der Lymphocyten. VIII. Fortsetzung der Studien über das Blut und die blutbildenden und -zerstörenden Organe. Arch. f. mikr. Anat., Bd. 75, S. 435. 
GrünbeRg, C. 1901 Beiträge zur vergleichenden Morphologie der Lencocyten. Virch. Arch., Bd. 163, S. 303.

JORDAN, H. E. $1910 \Lambda$ mieroscopical study of the umbilical vesicle of a 13-mm. human embryo, with especial reference to the entodermal tubules and the blood islands. Anat. Anz., Bd. 37, S. 12, 36 .

1916 Evidence of the hemogenic capacity of endothelium. Anat. Rec., vol. 10, p. 417.

Jondan, H. E., And Fltppin, J. C. 1913 Haematopoiesis in Chelonia. Folia Haemat., Bd. 15, S. 1.

KrES. P. 1915 The physiological destruction of erythrocytes in birds. Int. Monatschr. f. Anat. u. Phys., Bd. 31,.

Lanine, P. 1912 Des globules blanes ćosinophiles dans le sang des poissons d'eau douce. Arch. de Biol., T. 37, p. 525.

Maximow, A. 1909 a Untersuchungen über Blut und Bindegewebe. I. Die frühesten Entwicklungsstadien der Blut- und Bindegewebezellen beim Säugetierembryo, bis zum Anfang der Blutbildung in der Leber. Arch. f. mikr. Anat., Bd. 73, S. 444.

$1909 \mathrm{~b}$ Untersuchungen über Blut und Bindegewebe. II. Ưber die Histogenese der Thymus bei Säugetieren. Arch. f. mikr. Anat., Bd. 74 , S. 525 .

$1909 \mathrm{c}$ Über zweckmässige Methoden für cytologisehe und histogenetische Untersuchungen am Wirbeltierembryo, mit spezieller Berücksichtigung der Celloidinschnittserien. Zeit. f. wiss. Mikr., Bd. 26, S. 177.

1909 d Der Lymphocyt als gemeinsame Stammzelle der verschiedenen Blutelemente in der embryonalen Entwicklung und im postfetalen Leben der Säugetiere. Folia Hacmat., Bd. 8, S. 125.

1910 Über embryonale Entwicklung der Blutzellen bei Selachiern und Amphibien. Anat. Anz. Ergänzungsh., Bd. 37, S. 64.

1912 Untersuchungen über Blut und Bindegewebe. IV. Über die Histogenese der Thymus bei Amphibien. Areh. f. mikr. Anat., Bd. 79 , S. 560 .

1913 Untersuchungen über Blut und Bindegewebe. VI. Über Blutmastzellen. Arch. f. mikr. Anat., Bd. 83, s. 247.

Mtetens, H. 1909 Die Entstehung des Blutes bei Bufo vulgaris. Jen. Zeit. f. Natwschft., Bd. 45, S. 299.

1910 Entstehung der weissen Blutkörperchen und der Mílz bei Bufo vulgaris. Jen. Zeit. f. Natwschft., Bd. 46, S. 301.

Minot, C. S. 1912 Die Entstehung des Angioblasts und die Entwicklung des Blutes. Keibel u. Mall Handb. d. Entwick. d. Menschen, Bd. 2, S. 483.

Niggelewski, F. 1894 Die Ehrlich'sche Granulation der wcissen Blutkörperchen bei einigen Tierspezies. Inaug. Diss. München, 1894.

OPPEL, A. 1892 Unsere Kenntniss von der Entstehung der rothen und weissen Blutkörperchen. Zusammenfassendes Referat. CentbI. f. allg. Path. u. path. Anat., Bd. 3, S. 241, Bd. 4, S. 193. 
REAGAN, F. P. 1915 a Vascularization phenomena in sagments of embryonic bodies completely isolated from yolk-sac blastoderm. Anat. Rec., vol, 9 , p. 324 .

$1915 \mathrm{~b}$ A further study of the origin of blood vascular tissues in chemically treated teleost embryos, with especial reference to haenapoiesis in the anterior mesenchyme and in the heart. Anat. Rec., vol. 10, p. 99 .

1917 Experimental studies on the origin of vascular endothelium and of erythrocytes. Am. Jour. Anat., vol. 21, p. 39.

Reagan, F. P., and Thorington, J. M. 1915 The vascularization of the cmbryonic body of hybrid teleosts without eirculation. Anat. Rec., vol. 10, p. 79 .

Ringoen, A. R. 1915 Observations on the differentiation of the granules in the eosinophilic leucocytes of the bone marrow of the adult rabbit. Anat. Rec., vol. 9, p. 683.

Stockard, C. R. 1915 a The origin of blood and vaseular endothelium in embryos withont a circulation of the blood and in the normal embryo. Am. Jour. Anat., vol. 18, p. 227.

$1915 \mathrm{~b} A$ study of the wandering mesenchymal cells on the living yolk-sac and their developmental products; ehromatophores, vascular endothelium, and blood cells. Am. Jour. Anat., vol. 18, p. 525.

Schridote, II. 1907 Die Entstehung der ersten embryonalen Blutzellen des Mensohen. Folia Haemat., Bd. 4, Sup., S. 157.

1908 Die Entstehung der ersten embryonalen Blutzellen des Menschen. Verh. deutsch. path. Ges., XI. Vers., Dresden, 1908, S. 360.

VAN der Stricht, O. 1891 Le dóveloppoment du sang dans le foie embryonnaire. Arch. de Biol., T. 11, p. 19.

1892 Nouvelles recherehes sur la genèse des globules rouges et des globules blanc.s du sang. Arch. de Biol., T. 12, p. 199.

1895 De la première origin du sang et des capillaires sanguins dans l'aire vasculaire du lapin. C. R. Soc. Biol, , T. 47, p. 181.

1899 L'origin dos premières cellules sanguines et des premiers vaisseaux sanguins dans l'aire vasculaire de chauversouris. Bull. de l'Acad. R. de Med. Belg., Ser. 4, T. 13, p. 336.

Weber, A. 1907 a Formes de tranzition cntre les ébauches vasculaires et les îlots sanguines dans l'aire opaque dez embryons de canard. C. R. Soc. Biol., T. 62, p. 762 .

1907 b Remarques sur la dśveloppement des vaisseaux et du sang dans l'aire vasculaire de l'embryon du canard. C. R. Soc. Anat. Lille, 1937 , p. 18.

1914 Inclusion mixté a la gelatin et a la paraffine. Bibliog. Anat, T. 14, p. 146 .

Werdenteich, F. 1911 Die Leucocyten und verwandte Zellformen. Wiesbaden, 1911.

Werzbercx, A. Studien zur vergleichenden Haemocytologie einiger poikilothermer Vertebraten. Folia Haemat., Bd. 11, S. 17. 
PLATE 
PLATE 1

\section{EXPLANATION OF FIGURES}

All the figures represent preparations stained with eosin-azure II, and are drawn with the camera, using a B. \& L. 1/12-inch immersion objective with the 1-inch eye-piece.

1 Section through the ventral sinus of a 3.5- to 4-mm. larva.

2 Head mesenchyme of a 3.5- to 4-mm. larva.

3 Section through heart wall and cavity of a 5.6- to 6-mm. larva.

4 Erythrocytes of a 6.5- to 7-mm. larva.

5 Erythrocytes from the heart of an 8- to 8.5-mm. larva.

6 Section of the anlage of mesonephros of a 9-mm. larva.

7 Section through the mesonephros of a 16-mm. larva.

\section{ABBREVIATIONS}

e.c., eosinophile granulocyte e.end., eosinophil endothelium cell en.c., endocardium cell end., endothelium cell $l . l b$. , large lymphoblast l.lc., large lymphocyte l.w.c., lymphoid wandering cell m.c., mast cell $m s .$, mesenchyme cell p.b.c., primitive blood-cell p.eb., primitive erythroblast p.ec., primitive erythrocyte s.c., special cell s.lc., small lymphocyte sp.c., spindle cell w., mesonephric tubule 


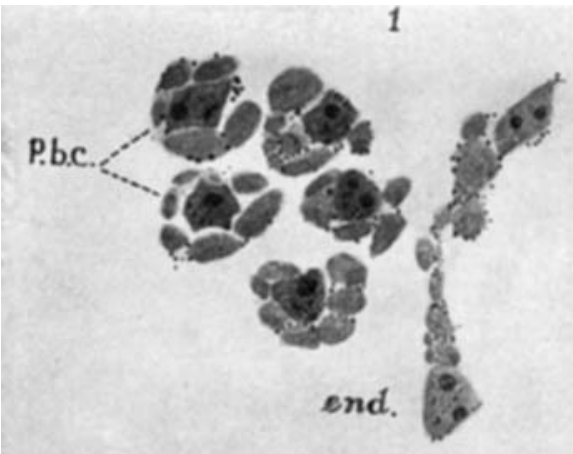

3
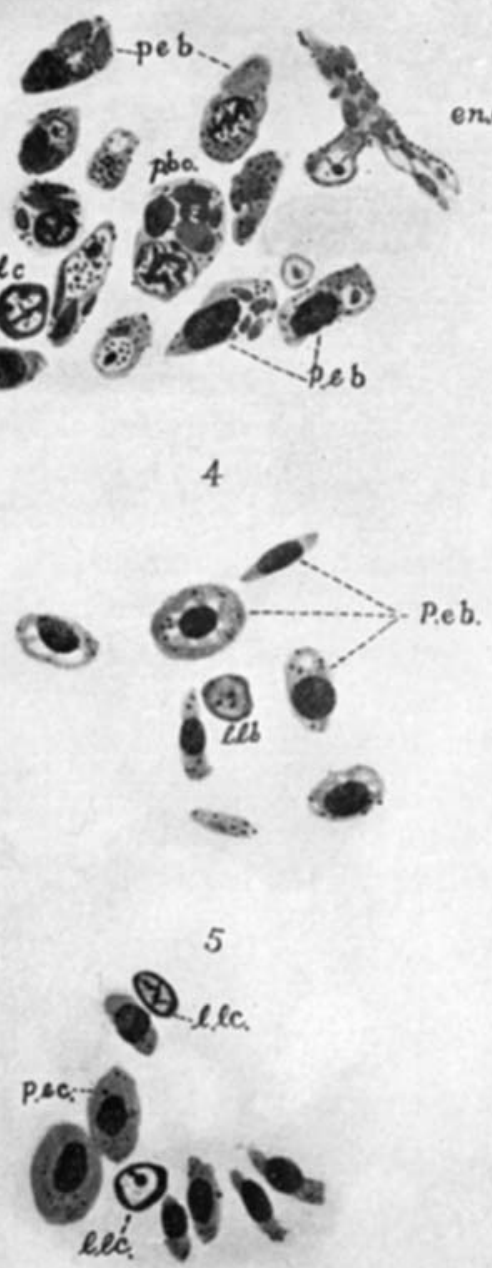

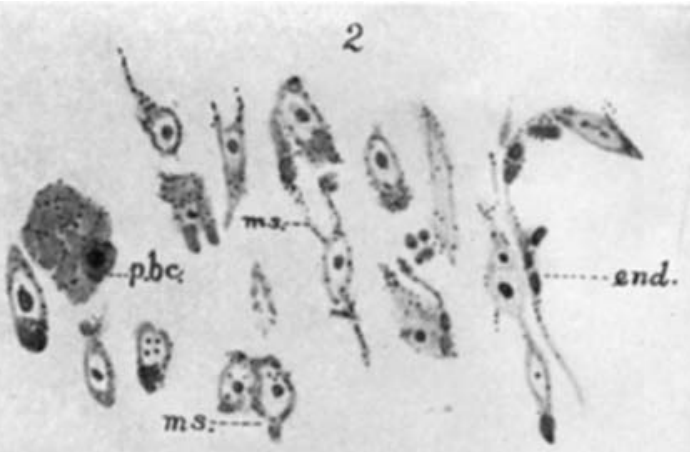

6

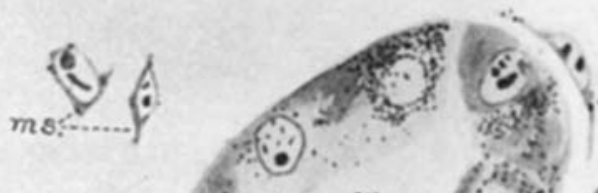

(1): $u$
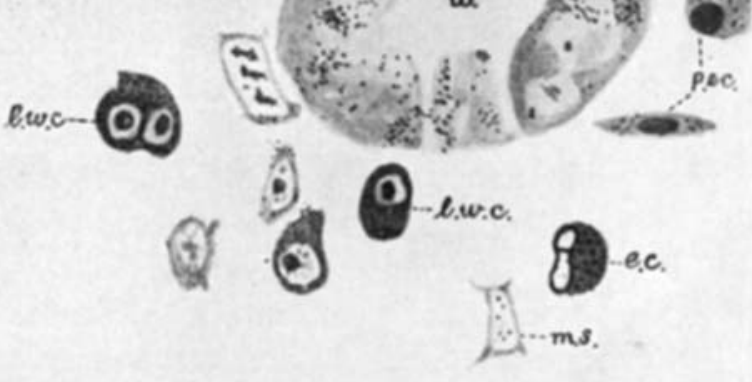

7

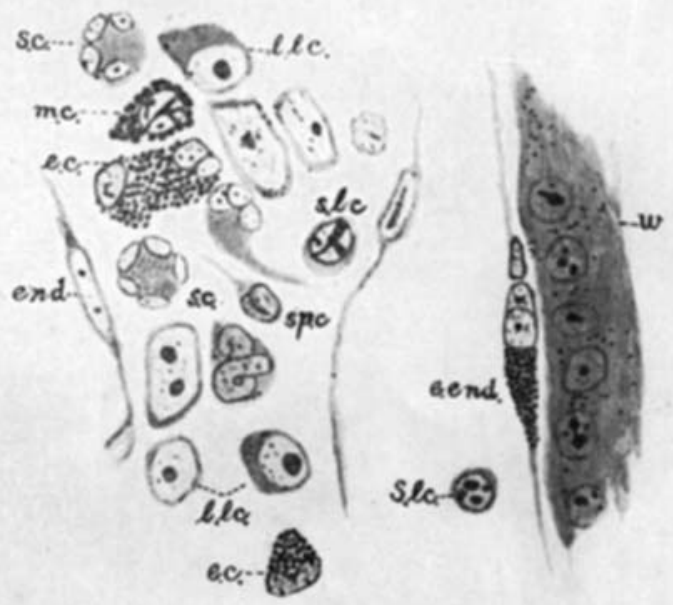

